Scientia Marina 71(1)

March 2007, 65-74, Barcelona (Spain)

ISSN: 0214-8358

\title{
Hydromedusae (Cnidaria) of the Chilean southern channels (from the Corcovado Gulf to the Pulluche-Chacabuco Channels)
}

\author{
SERGIO PALMA, PEDRO APABLAZA and NELSON SILVA \\ Escuela de Ciencias del Mar, Pontificia Universidad Católica de Valparaíso, P.O. Box 1020, Valparaíso, Chile. \\ E-mail: spalma@ucv.cl
}

\begin{abstract}
SUMMARY: Hydromedusae collected in epipelagic waters of the channels in southern Chile, between the Corcovado Gulf and the Pulluche-Chacabuco channels, were analysed. A total of 23 species were identified and recorded for the first time in this region. The most abundant species were Hydractinia minuta (44.4\%), Clytia spp. (21.0\%), Solmundella bitentaculata (14.5\%), and Amphogona apicata (9.8\%). H. minuta was the only species whose maximum abundance occurred in interior, low temperature, low salinity waters. Most of the species identified in the southern channels are common inhabitants of the Humboldt Current System, although a rare species (Heterotiara minor) was recorded for the first time in Chilean waters. High-diversity values ( $>2.5$ bits) were recorded in the oceanic waters of the adjacent Pacific Ocean.
\end{abstract}

Keywords: Hydrozoa, medusae, distribution, diversity, southern channels, Chile.

RESUMEN: Hydromedusas (CNidaria) de los canales del sur de Chile (Del Golfo Corcovado a los Canales PulluChe-CHACABUCO). - Se analizaron las hidromedusas colectadas en aguas epipelágicas de los canales del sur de Chile, entre el golfo Corcovado y los canales Pulluche-Chacabuco. Se identificó un total de 23 especies de hidromedusas, todas ellas registradas por primera vez en esta región y Heterotiara minor fue registrada por primera vez en aguas chilenas. Las especies más abundantes fueron Hydractinia minuta (44.4\%), Clytia spp. (21.0\%), Solmundella bitentaculata (14.5\%), y Amphogona apicata $(9.8 \%)$. H. minuta fue la única especie cuya abundancia máxima ocurrió en aguas interiores de baja temperatura y baja salinidad. La mayoría de las especies identificadas en los canales australes son habitats comunes del Sistema de la Corriente de Humboldt. Los mayores valores de diversidad ( $>2.5$ bits) se estimaron en aguas oceánicas del Pacífico adyacente.

Palabras clave: Hidrozoos, medusas, distribución, diversidad, canales australes, Chile.

\section{INTRODUCTION}

Over the last ten years, a systematic research programme has been carried out in southern Chile, particularly in the interior waters of the fjords and channels, resulting in significantly increased knowledge and understanding of the oceanographic and zooplankton characteristics of the interior waters between Puerto Montt and Cape Horn (Palma and Silva, 2004).
Zooplankton studies in Chile's southern fjords and channels have focused on chitinous organisms such as copepods, euphausiids, and the larvae of decapod crustaceans (Guglielmo and Ianora, 1995, 1997; Mujica and Medina, 1997, 2000; Palma et al., 1999; Marín and Delgado, 2001; Palma and Aravena, 2001) and some gelatinous (siphonophores) or semigelatinous (chaetognaths) organisms (Palma and Rosales, 1997; Palma et al., 1999; Palma and Aravena, 2001, 2002). Although 
hydromedusae are common to all the oceans, no information is available regarding these conspicuous gelatinous organisms in this extensive southern channel region except for the work of Pagès and Orejas (1999), which describes the presence of 17 species around the Strait of Magellan.

Hydromedusae are also known as craspedota medusae because they have velum and several species have a metagenetic life cycle, and because their sexual stage consists of an alternation in which asexual polyps are generated. The geographic distribution of these largely epipelagic planktonic organisms is closely associated with coastal waters. Several species of hydromedusae have a high capacity of asexual reproduction and they can form dense aggregates in these areas, especially during the warmest periods of the year. Gelatinous organisms frequently invade coastal upwelling areas, taking advantage of the greater trophic availability (Pagès, 1992; Palma and Rosales, 1995; Palma and Apablaza, 2004). Recent studies show a steady increase in the populations of gelatinous organisms in diverse marine areas (Mills, 2001; Brodeur et al., 2002). These organisms play a preponderant role in zooplankton structure and dynamics due to the heavy impact of their predatory activity (Matsakis and Conover, 1991). Some medusae species have also proliferated in the interior waters of Chile's southern region. In fact, from February to June 2002, proliferations of Aequorea coerulescens, Chrysaora plocamia, and Phacellophora camtschatica affected salmon farming installations in the interior waters off Chiloé Island, with high mortality rates for the farmed fish (unpublished data).

The purpose of the present study was to investigate the composition, abundance, and diversity of hydromedusae and their relationship with the oceanographic conditions present in the southern Chilean channels, between the Corcovado Gulf and the Pulluche-Chacabuco channels.

\section{MATERIALS AND METHODS}

During the CIMAR 8 Fiordos Cruise (16-24 November 2002), 38 oceanographic stations were sampled in one longitudinal (Corcovado GulfMoraleda Channel) and several transverse channels (Tuamapu, King, Ninualac, Darwin, Chacabuco, and Pulluche channels) between the Corcovado Gulf $\left(43^{\circ} 40^{\prime} \mathrm{S}\right)$ and the Pulluche-Chacabuco channels

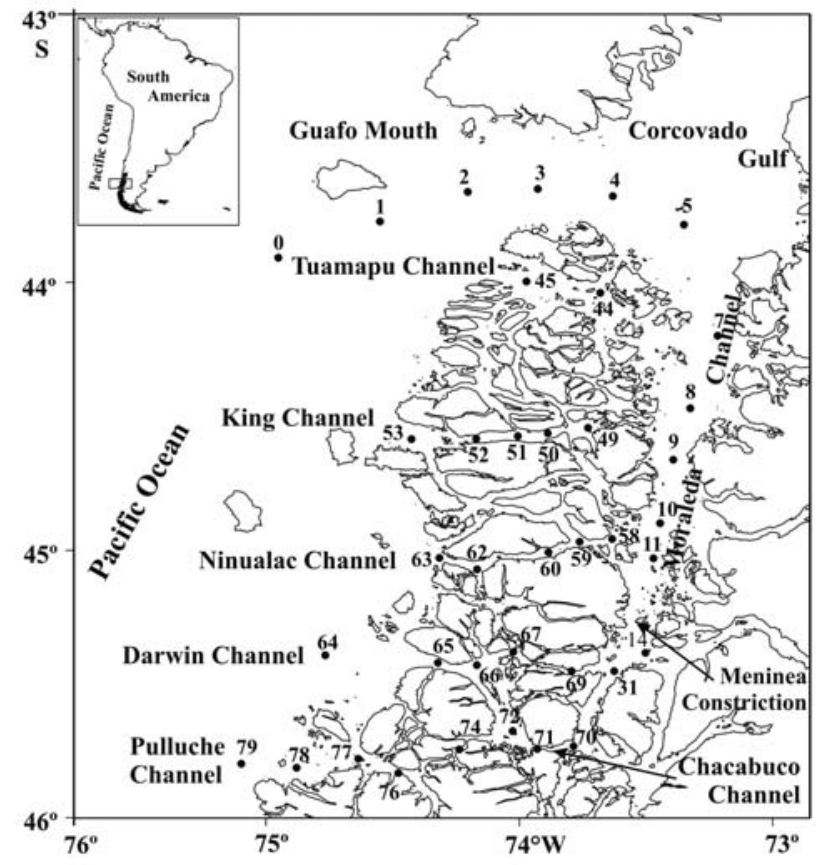

FIG. 1. - Geographic location of sampling stations in the southern Chilean channels.

( $45^{\circ} 47^{\prime}$ S) (Fig. 1). Vertical profiles were taken for temperature, salinity, and dissolved oxygen with a CTDO SeaBird 25. The maximum sampling depth was $300 \mathrm{~m}$ (Rojas et al., 2005). The CTDO did not work properly at Stations 0 to 3 at the Guafo Mouth. Water masses were analysed based on T-S diagrams according to Silva et al. $(1997,1998)$.

At all stations, zooplankton catches were made with oblique tows from a maximum of $200 \mathrm{~m}$ to the surface, using Bongo nets $(60 \mathrm{~cm}$ diameter, $350 \mu \mathrm{m}$ mesh). The nets were equipped with flowmeters to estimate the volume of water filtered. Plankton samples were taken with day and night-time hauls. Specimens were conserved in seawater with 5\% borax buffered formalin and deposited in the collection of Laboratorio de Planctología, Escuela de Ciencias del Mar, Pontificia Universidad Católica de Valparaíso, Chile. All species were identified based on the current status of taxonomic information and classification (Bouillon et al., 2004). The geographic distribution of the medusae was analysed according to the dominant species, which were considered to be those whose abundance was greater than $5 \%$ of the total collected specimens.

A cluster analysis was carried out using the $\log$ $(x+1)$ relative abundance transformation to describe the species' distribution patterns, and to determine the sample group with the greatest specific affinity. The Bray-Curtis Index of Similarity (Bloom, 1981) 
was used to perform the clusters analysis. Furthermore, we estimated the Shannon-Wiener Diversity Index (ind bits ${ }^{-1}$ ) and Pearson's correlation coefficient between the relative abundance of dominant species and surface values of temperature and salinity in the study area.

\section{RESULTS}

\section{Oceanographic characteristics}

Due to the scope of this paper, only the most important oceanographic features for understanding

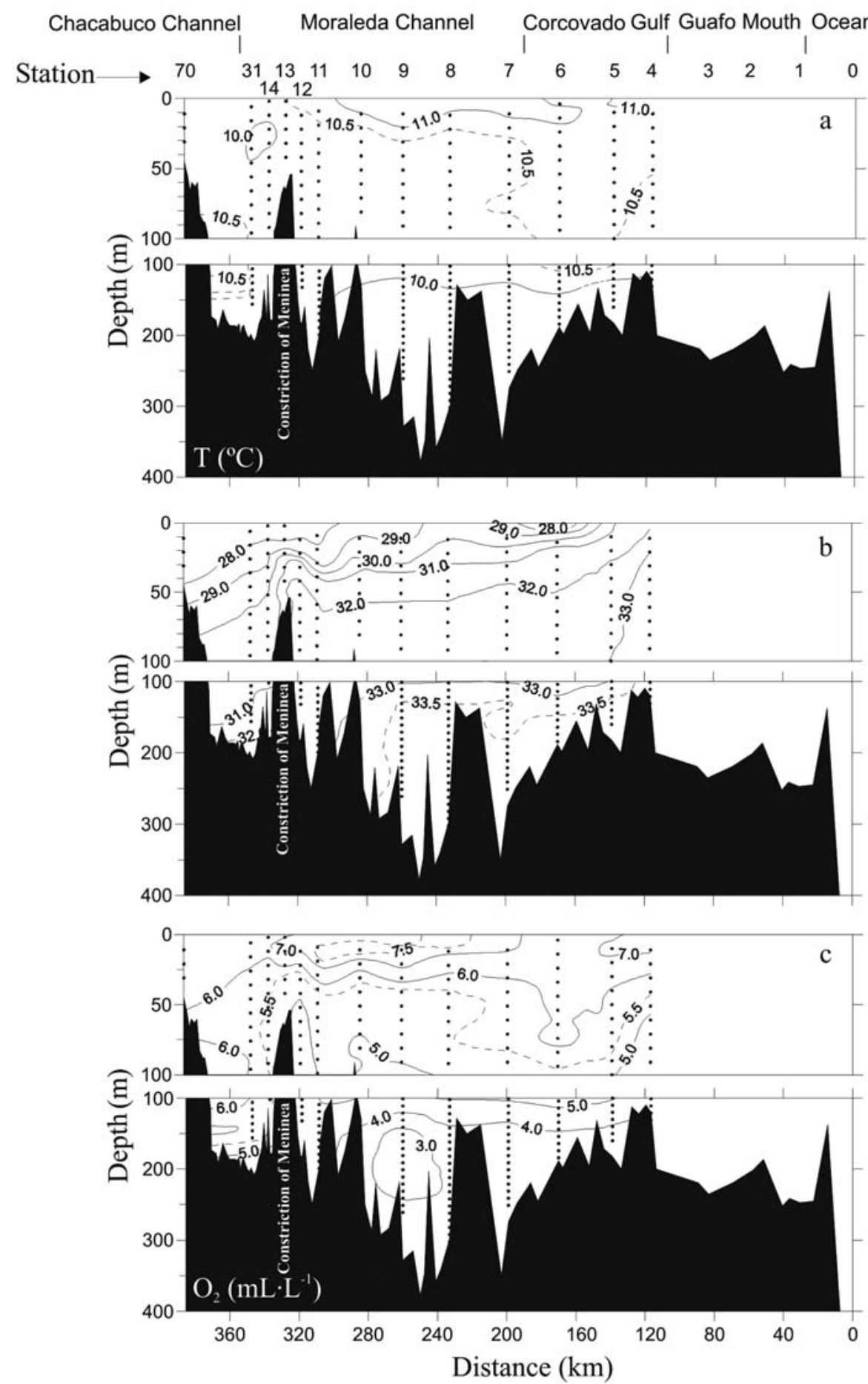

FIG. 2. - Vertical distribution of a) temperature, b) salinity, and c) dissolved oxygen in an oceanographic transect between the Guafo Mouth and the Chacabuco Channel. 
the geographic distribution of the hydromedusae are analysed. The vertical temperature distribution was very homogenous between the Corcovado Gulf and the Chacabuco Channel (Fig. 2). In the longitudinal section, surface temperatures fluctuated between 10.5 and $11.0^{\circ} \mathrm{C}$, the highest temperatures being found in the Moraleda Channel. In this section, the vertical temperature distribution was very homogeneous and no seasonal thermocline was present (Fig. 2). Surface salinity values (32; Corcovado Gulf) decreased gradually toward the south (28; Meninea Constriction). Vertical salinity distribution showed a strong halocline, especially in the upper $50 \mathrm{~m}$. Below $50 \mathrm{~m}$, salinity was higher to the north of the Meninea Constriction (32-33) and lower to the south of it (30-31). The high dissolved oxygen levels (> 6 $\mathrm{mL} \mathrm{L}^{-1}$ ) at the surface decreased to $150 \mathrm{~m}$ depth and were lower to the north of the Meninea Constriction (3-4 $\left.\mathrm{mL} \mathrm{L}^{-1}\right)$ and higher to the south of it $(5-6 \mathrm{~mL}$ $\mathrm{L}^{-1}$ ) (Fig. 2).

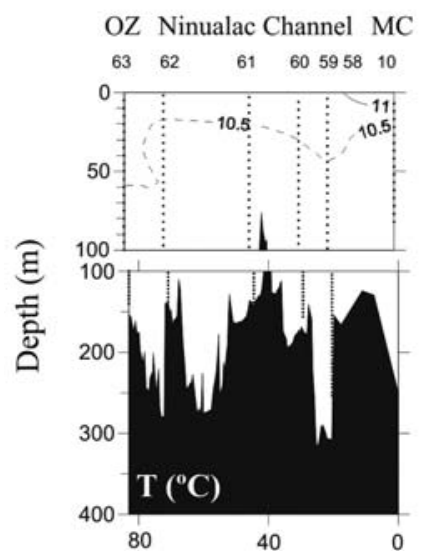

$\mathrm{OZ}$ Darwin Channel MC

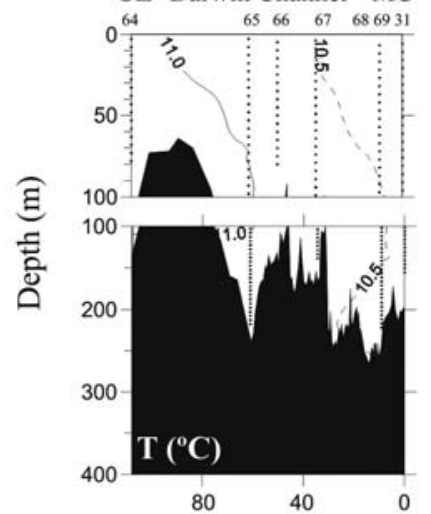

$\begin{array}{lcc}80 & 40 & 0\end{array}$

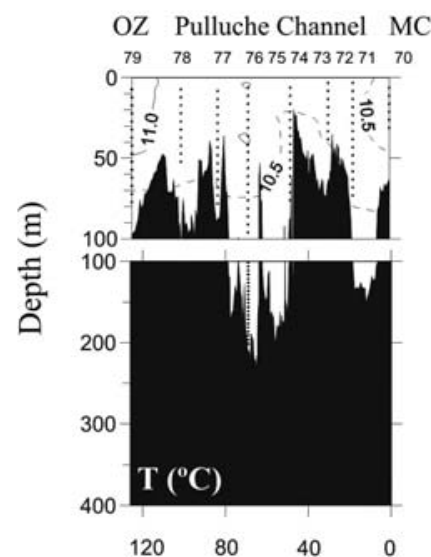

$\mathrm{OZ}$ Ninualac Channel MC $6362 \quad 61 \quad 60595010$
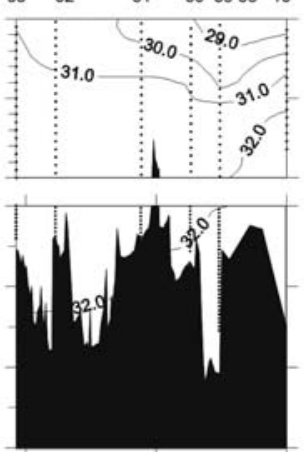

80

40

$\mathrm{OZ}$ Darwin Channel $\mathrm{MC}$
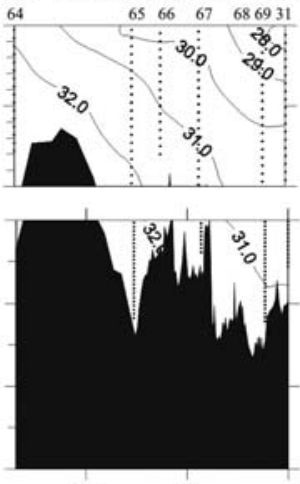

$80 \quad 40$

OZ Pulluche Channel MC $\begin{array}{lllll}79 & 78 & 77 & 767574737271 \quad 70\end{array}$
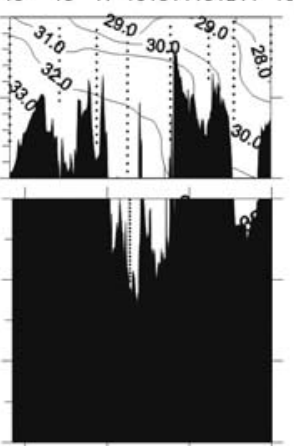

$120 \quad 80 \quad 40 \quad 0$

Distance $(\mathrm{km})$
OZ Ninualac Channel MC

$\begin{array}{llll}63 & 62 & 61 & 60\end{array}$
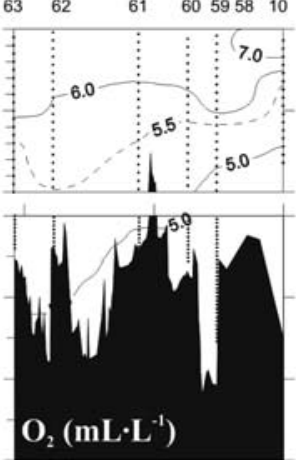

80

$\mathrm{OZ}$ Darwin Channel MC
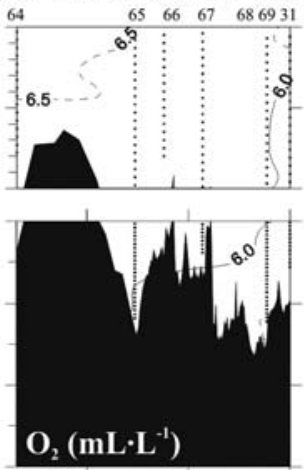

$\begin{array}{lll}80 & 40 \quad 0\end{array}$

OZ Pulluche Channel MC

$\begin{array}{lllll}79 & 78 & 77 & 767574737271 & 70\end{array}$

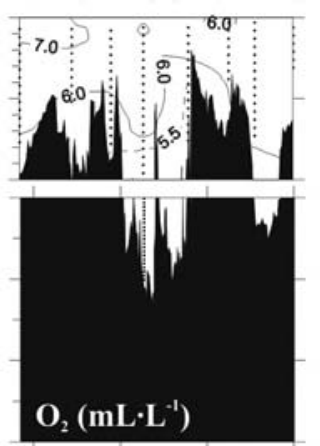

$120 \quad 80 \quad 40 \quad 0$

FIG. 3. - Vertical distribution of temperature, salinity, and dissolved oxygen in the Ninualac, Darwin, and Pulluche channels. OZ: Oceanic Zone, MC: Moraleda Channel. 

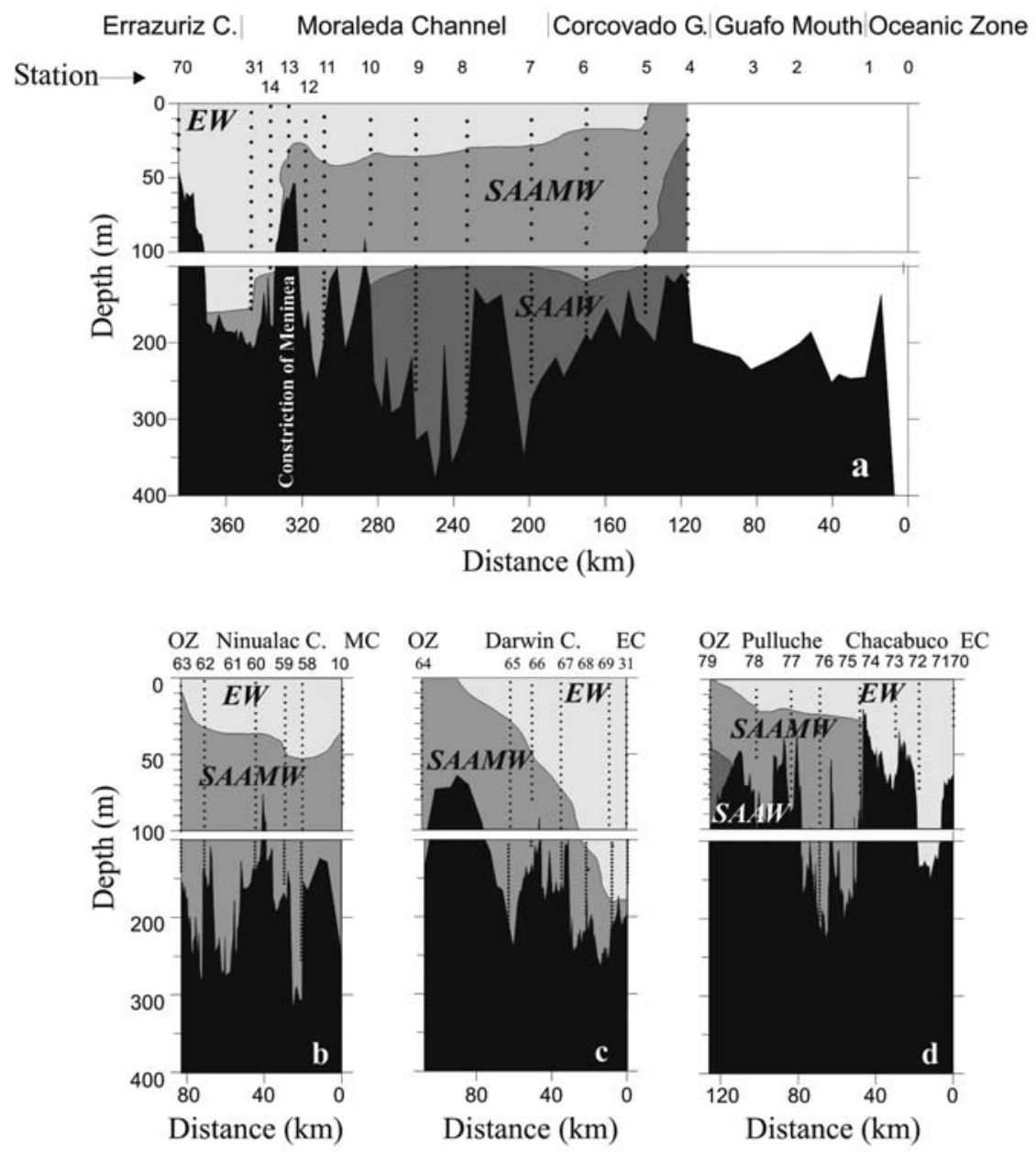

FIG. 4. - Vertical distribution of water masses in the study area, a) Moraleda Channel, b) Ninualac Channel, c) Darwin Channel, and d) Pulluche-Chacabuco channels. OZ: Oceanic Zone, MC: Moraleda Channel, EC: Errázuriz Channel, EW: Estuarine Water, SAAW: Sub-Antarctic Water, SAAMW: Sub-Antarctic Modified Water.

The vertical sections of the transverse channels (Ninualac, Darwin, and Pulluche) were similar to those of the longitudinal channel described above. The most characteristic features in these channels were increased surface salinity from east (interior waters; 28-29) to west (adjacent Pacific Ocean waters; 32-33) and the absence of low-oxygen waters $\left(<2.5 \mathrm{~mL} \mathrm{~L}^{-1}\right)$ near the bottom (Fig. 3).

According to the T-S diagrams (not shown) and the descriptions in Silva et al. (1997), three water masses have been identified in this area:

a) Sub-Antarctic Water (SAAW), 0-100 m, from the adjacent coastal zone enters through the Guafo Mouth into the Moraleda Channel and sinks below $100 \mathrm{~m}$ depth. However, it does not enter the Moraleda and Errázuriz channels through the transverse channels. The temperature of SAAW ranges between 9 and $13^{\circ} \mathrm{C}$, salinity of between 33.0 and 33.9, and dissolved oxygen between 5 and $8 \mathrm{~mL} \mathrm{~L}^{-1}$.

b) Sub-Antarctic Modified Water (SAAMW), characteristic of the upper layer (30-100 $\mathrm{m}$ ) in interior channels and distinguished by a salinity of between 31 and 33 .

c) Estuarine Water (EW) in the upper layer (0-50 $\mathrm{m})$ of the inner channels, characterised by lower salinity (2 to 31 ). SAAMW and EW are formed when SAAW is mixed with variable amounts of fresh water from rain, rivers, and glacial melting as SAAMW penetrates towards the continental channels and fjords (Fig. 4).

\section{Species composition and distribution}

In total, 23 species of hydromedusae were identified (Table 1) and recorded in this zone (43040'$\left.45^{\circ} 47^{\prime} \mathrm{S}\right)$ for the first time. Moreover, Heterotiara minor was registered for the first time ever in Chilean waters. Dominant species were: Hydractinia (=Podocoryna) minuta (44.4\%), Clytia spp. (21.0\%), Solmundella bitentaculata (14.5\%), and Amphogona 
TABLE 1. - Mean abundance, standard deviation, total abundance and percentage of hydromedusae collected in the study area. Asterisk indicates the species recorded in the Magellan region by Pagès and Orejas (1999).

\begin{tabular}{|c|c|c|c|c|}
\hline Species & $\begin{array}{c}\text { Mean } \\
\text { (ind } 1000 / \mathrm{m}^{3} \text { ) }\end{array}$ & $\begin{array}{r}\text { Standard } \\
\text { deviation }\end{array}$ & $\begin{array}{l}\text { Total abundance } \\
\text { (ind } / 1000 \mathrm{~m}^{3} \text { ) }\end{array}$ & $\begin{array}{c}\text { Percentage } \\
(\%)\end{array}$ \\
\hline Hydractinia minuta (Mayer, 1900) * & 1867.9 & 6884.0 & 70981 & 44.4 \\
\hline Clytia spp. & 882.1 & 1344.1 & 33519 & 21.0 \\
\hline Solmundella bitentaculata (Quoy and Gaimard, 1833)* & 611.3 & 792.0 & 23231 & 14.5 \\
\hline Amphogona apicata Kramp, $1957 *$ & 413.9 & 512.1 & 15727 & 9.8 \\
\hline Obelia spp. * & 135.0 & 255.4 & 5128 & 3.2 \\
\hline Bougainvillia sp. * & 60.9 & 94.9 & 2315 & 1.4 \\
\hline Proboscidactyla ornata (McCrady, 1857) & 56.2 & 119.2 & 2137 & 1.3 \\
\hline Hydromedusa sp. 1 & 35.3 & 60.1 & 1340 & 0.8 \\
\hline Rhopalonema velatum Gegenbaur, 1856 * & 27.6 & 50.6 & 1051 & 0.7 \\
\hline Phialella quadrata (Forbes, 1848) & 26.3 & 94.0 & 1000 & 0.6 \\
\hline Euphysa aurata Forbes, $1848 *$ & 23.7 & 40.8 & 901 & 0.6 \\
\hline Leuckartiara octona (Fleming, 1823) * & 14.4 & 28.3 & 545 & 0.3 \\
\hline Halopsis ocellata A. Agassiz, $1863 *$ & 13.3 & 43.0 & 506 & 0.3 \\
\hline Liriope tetraphylla (Chamisso and Eysenhardt, 1821) & 10.0 & 20.1 & 378 & 0.2 \\
\hline Proboscidactyla stellata (Forbes, 1846) & 9.9 & 15.4 & 375 & 0.2 \\
\hline Hydractinia borealis (Mayer, 1900) * & 7.3 & 28.6 & 278 & 0.2 \\
\hline Proboscidactyla mutabilis (Browne, 1902) * & 3.1 & 6.2 & 119 & 0.1 \\
\hline Cunina peregrina Bigelow, 1909 & 2.9 & 8.7 & 108 & 0.1 \\
\hline Amphinema rugosum (Mayer, 1900) * & 2.2 & 6.2 & 85 & 0.1 \\
\hline Aglaura hemistoma Péron and Lesueur, 1810 & 1.5 & 6.6 & 58 & 0.01 \\
\hline Sarsia eximia (Allman, 1859) & 1.3 & 4.6 & 48 & 0.01 \\
\hline Ectopleura dumortieri (van Beneden, 1844) & 0.4 & 1.7 & 15 & 0.01 \\
\hline Heterotiara minor Vanhöffen, 1911 & 0.3 & 2.1 & 13 & 0.01 \\
\hline Dipurena sp. & 0.2 & 1.0 & 6 & 0.01 \\
\hline
\end{tabular}

apicata $(9.8 \%)$. Clytia spp. was the most frequently observed species, being present at $97.4 \%$ of the sampled stations. The remaining species were scarce and some (e.g. Heterotiara minor and Dipurena sp.) were found at only one station.

Medusae were found throughout the study area and were most abundant in interior waters. Abundance fluctuated between $193 \mathrm{ind} / 1000 \mathrm{~m}^{3}$ at Station 45 at the west end of the Ninualac Channel and 42500 ind $/ 1000 \mathrm{~m}^{3}$ at Station 14 in the Moraleda Channel; the average per station was 4172 ind $/ 1000 \mathrm{~m}^{3}$. A general east-west decrease in the total abundance distribution was found in the transverse channels (Fig. 5).

The predominant species, Hydractinia minuta, was distributed mainly in interior waters, with the greatest densities in the eastern segments of the Ninualac, Darwin, and Chacabuco channels and a maximum of $41032 \mathrm{ind} / 1000 \mathrm{~m}^{3}$ at Station 14 . The lowest densities $\left(<260 \mathrm{ind} / 1000 \mathrm{~m}^{3}\right)$ were registered mainly in the oceanic waters, the Corcovado Gulf and the Moraleda Channel, and at the western stations of the transverse channels (Fig. 5a). In general, H. minuta populations were mostly made up of juveniles; most mature adult specimens were budding.

The second most abundant species, Clytia spp., was distributed widely throughout the study area. The highest densities were registered in the oceanic area off the Guafo Mouth, in the King Channel, and at some sta- tions in the Ninualac and Darwin channels, and a maximum of $7784 \mathrm{ind} / 1000 \mathrm{~m}^{3}$ was found at Station 51. Densities were lowest in the Corcovado Gulf and the Moraleda and Chacabuco channels (Fig. 5b). This was the only dominant species with high concentrations in the oceanic sector off the Guafo Mouth.

Solmundella bitentaculata was distributed throughout the study area, with peaks in the King and Ninualac channels. Density was highest (4152 ind/1000 $\left.\mathrm{m}^{3}\right)$ at Station 49 at the eastern tip of the King Channel and lowest in oceanic waters, the Corcovado Gulf, and the Chacabuco Channel (Fig. 5c).

Amphogona apicata was also found throughout the study area. Densities for this species were highest in the Ninualac Channel (maximum 2410 ind $/ 1000 \mathrm{~m}^{3}$ ) at Station 58 and, as for H. minuta and $S$. bitentaculata, lowest in oceanic waters, the Corcovado Gulf, and the Darwin and Chacabuco channels (Fig. 5d).

Specimens of the remaining species were scarce and infrequent, except for Bougainvillia sp. (454 ind/1000 $\mathrm{m}^{3}$ ) and Obelia spp. (1206 ind/1000 m³), which were highly concentrated at some stations in the King and Pulluche channels, respectively.

\section{Similarity analysis}

Based on the Bray-Curtis similarity analysis, two groups of stations were defined (Fig. 6). The first, 

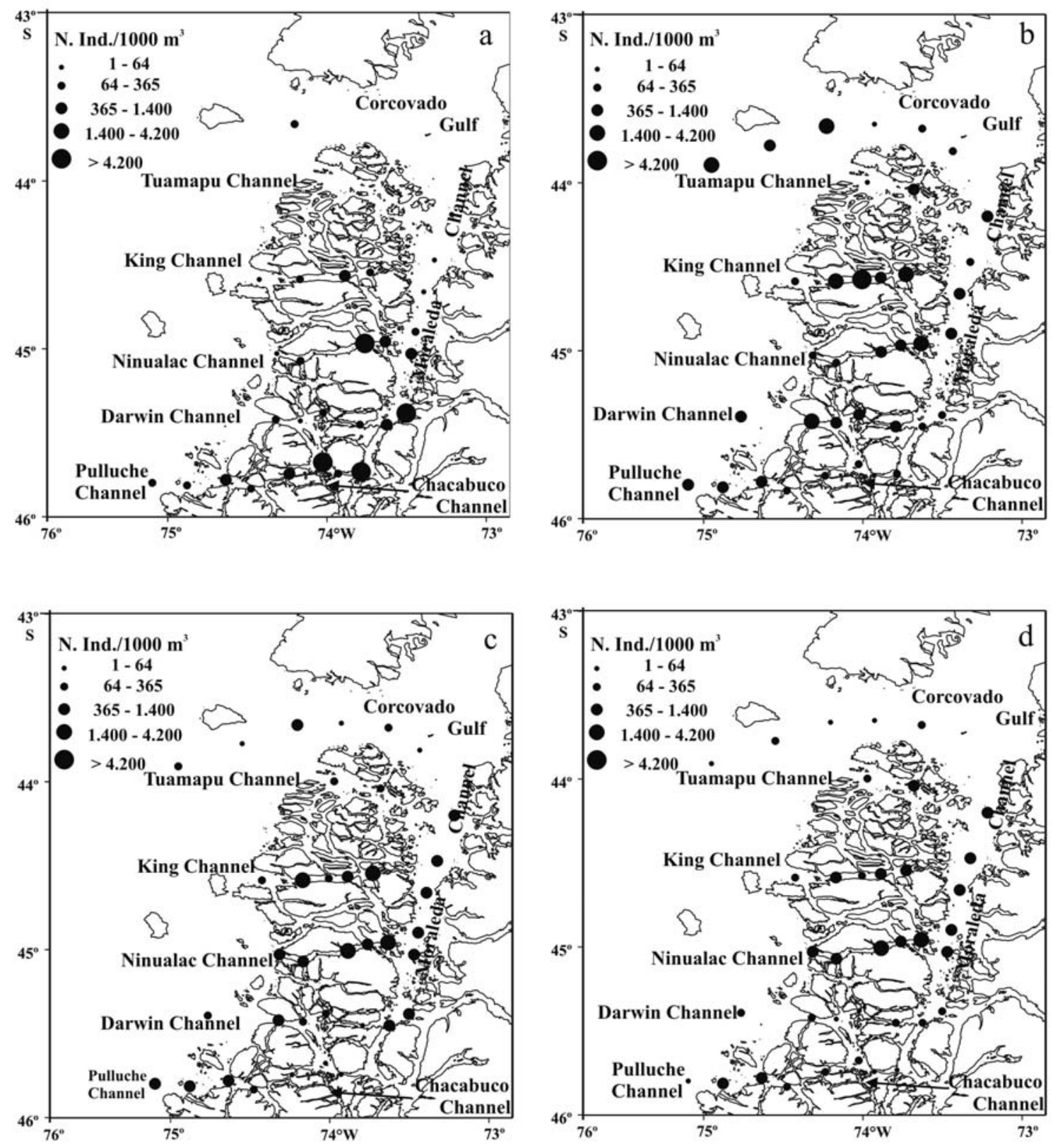

FIG. 5. - Geographic distribution and abundance of a) Hydractinia minuta, b) Clytia sp., c) Solmundella bitentaculata, and d) Amphogona apicata.

Group A, included a large number of analysed stations (82\%) whereas the second, Group B, consisted of a few stations (18\%) located in the most southeastern area and characterised by high densities of Hydractinia minuta.

\section{Diversity index}

Diversity index values fluctuated between 0.28 and 3.31 bits at Stations 3 and 14, respectively (Fig. 7 ). The greatest values ( $>2.5$ bits) were found at the Guafo Mouth and the western stations of the King,
Darwin, and Pulluche channels. Diversity was highest at the latter channel.

\section{Correlation coefficient}

Results of the correlation analysis between the relative abundance of dominant species and the surface values of oceanographic parameters showed significant values only for Hydractinia minuta and Clytia spp. (Table 2). H. minuta abundance was negatively correlated with temperature and salinity and Clytia spp. abundance was positively correlated with temperature. 


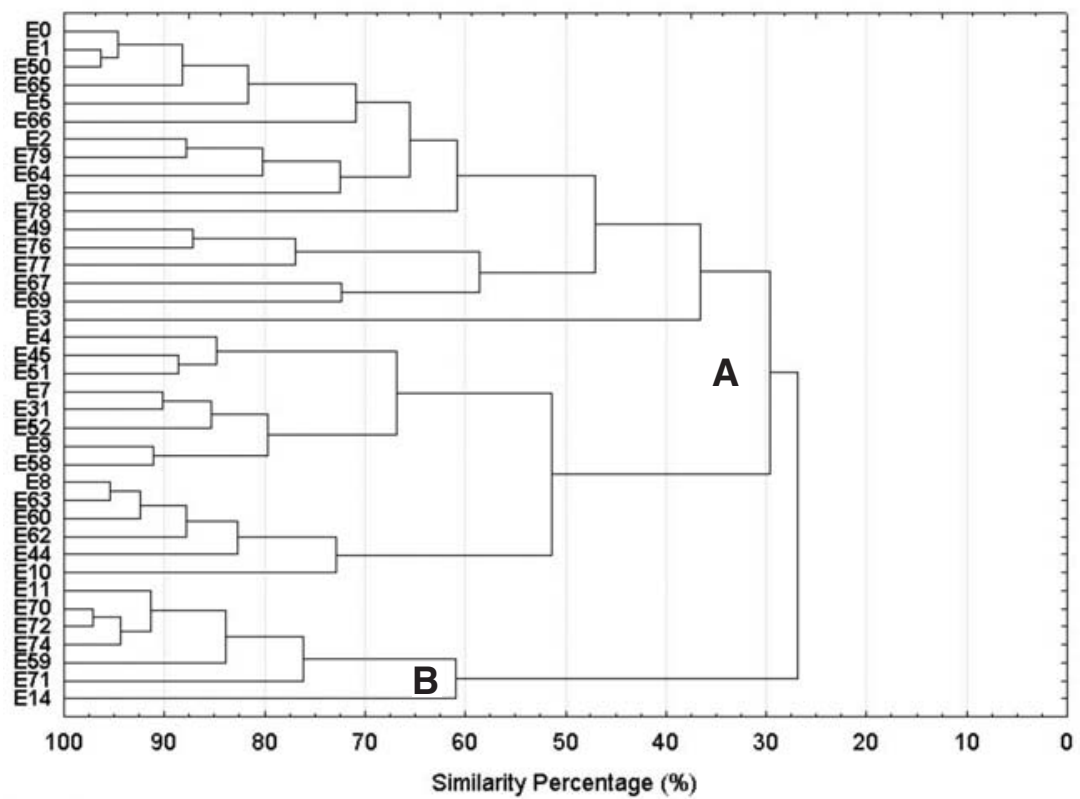

FIG. 6. - Dendrogram from analysis based on Bray-Curtis Index showing distribution of the clusters in the surveyed area.

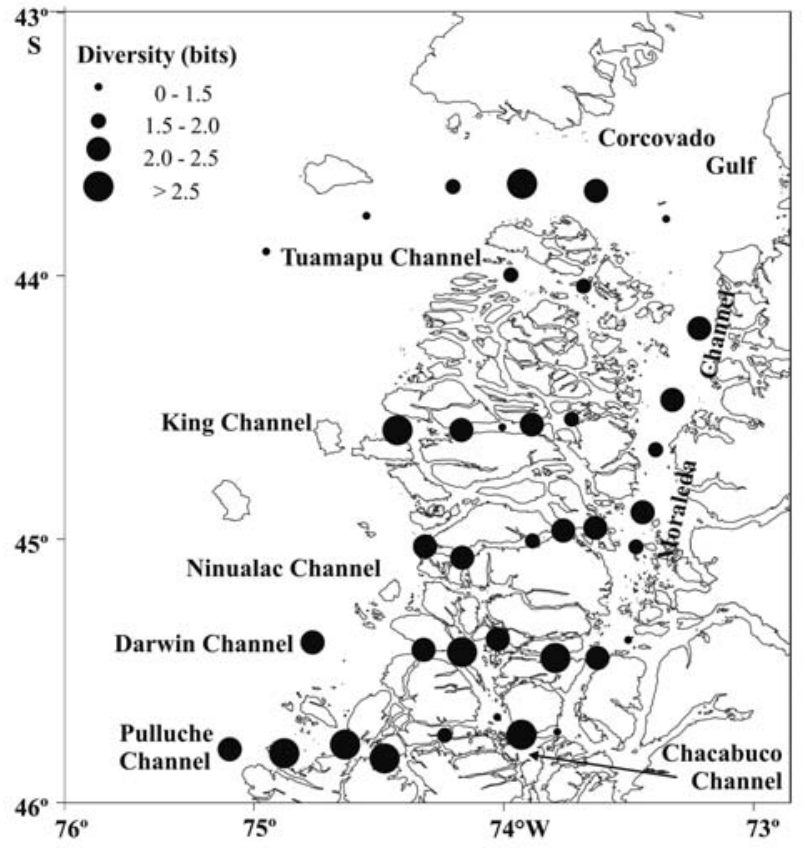

FIG. 7. - Diversity index of hydromedusae in the southern Chilean channels.

\section{DISCUSSION}

Our observations of oceanographic characteristics in the study area confirm those previously reported for this channel zone. However, on this occasion, bottom waters of the Corcovado Gulf and the Moraleda Channel did not show a salinity higher than 34.0 psu or a level of dissolved oxygen lower than $3.0 \mathrm{~mL} \mathrm{~L}^{-1}$. This implies the absence of rem- nants of ESSW in the Moraleda Channel, as found on previous cruises (Silva et al., 1997, 1998). The most characteristic feature is the variation in salinity between oceanic and interior waters (Silva et al., 1997, 1998; Guzmán and Silva, 2002). Low salinity oceanographic conditions generated in interior waters can affect the presence, distribution and aggregation of zooplanktonic organisms (Palma and Silva, 2004).

The geographic distribution of the hydromedusae (Fig. 5) was characterised by low densities at the Guafo Mouth and in the Corcovado Gulf due to lower stability in the vertical water column caused by wind mixing. This less environmentally stable area is characterised by low biomass values and zooplanktonic abundance (Mujica and Medina, 1997; Palma and Rosales, 1997; Palma and Silva, 2004). On the other hand, the areas with the greatest aggregates of medusae corresponded to eastern stations in the King, Ninualac, and Pulluche channels; these are characterised by lower salinity EW, which increases the water column stability (Fig. 7). The overall increase in the total abundance distribution from west to east in the transverse channels (Fig. 5) was probably associated with the west-east increase in water column stability. This characteristic is probably more suitable for the aggregation of this species. Most of the non-dominant medusae species occurred in low numbers, which is common in medusan communities. Furthermore, communities of planktonic cnidarians are frequently dominated 
TABLE 2. - Correlation values between the relative abundances and the environmental variables. Significant values are indicated in bold ( $\mathrm{p}<0.05)$.

\begin{tabular}{lcccc}
\hline & Hydractinia minuta & Clytia spp. & Solmundella bitentaculata & Amphogona apicata \\
\hline Hydractinia minuta & & & & \\
Clytia spp. & -0.21 & & & \\
Solmundella bitentaculata & -0.19 & 0.23 & $\mathbf{0 . 6 3}$ & -0.22 \\
Amphogona apicata & 0.15 & 0.08 & 0.03 & -0.09 \\
Temperature & $\mathbf{- 0 . 5 3}$ & $\mathbf{0 . 4 4}$ & -0.34 & -0.13 \\
Salinity & $\mathbf{- 0 . 6 6}$ & 0.20 & -0.07 & \\
Dissolved oxygen & -0.25 & & \\
\hline
\end{tabular}

by a few of the most common species, particularly in the southern Chilean channels (Palma and Rosales, 1997; Palma and Silva, 2004).

The known geographic distribution ranges (for Chilean waters) of all the species identified in this study increased due to the new geographic records presented herein. Heterotiara minor was observed for the first time in Chilean waters. Three quarters of the species identified in this area (Table 1) have also been observed in the Magellan channels (Pagès and Orejas, 1999) and the majority of the observed species are epipelagic and commonly found in the Humboldt Current System (HCS) (Kramp, 1966, 1968; Fagetti, 1973; Palma, 1994; Palma and Rosales, 1995; Palma and Apablaza, 2004).

Hydractinia minuta had the smallest geographic distribution of the dominant species and its largest aggregates were observed in interior waters (Figs. 5 and 6). Aggregates were observed in interior waters with low temperatures and salinity (Pearson, $\mathrm{r}=$ -0.53 and -0.66 respectively; Table 2) associated with EW, and the SAAMW found at the eastern end of the Ninualac, Darwin, and Pulluche channels (Fig. 4). In this area, the oceanic influence is weak, with low species diversity. This is confirmed by the Bray-Curtis clustering stations (Fig. 6). This species has also been found in very low numbers in the Magellan channels and is rare in temperate waters of both hemispheres (Pagès and Orejas, 1999).

Medusae of the genus Clytia were most abundant in the oceanic waters off the Guafo mouth and the King Channel (Fig. 5b). Clytia is made up of some twelve species, several of which are cosmopolitan and found mostly in temperate and warm waters (Kramp, 1968). In the HCS, Clytia medusae are common and abundant (Fagetti, 1973; Palma, 1994; Palma and Rosales, 1995; Pagès et al., 2001; Palma and Apablaza, 2004), with Clytia simplex probably the predominant species (Kramp, 1966). These results confirm the wide geographic distribution of this species off the Chilean coast (Kramp, 1966), and its abundance in low-salinity inner waters suggests a marked euryhaline nature.

The maximum abundances of Solmundella bitentaculata, registered in King and Ninualac channels (Fig. 5c), were two orders of magnitude greater than those registered in the Strait of Magellan (Pagès and Orejas, 1999). S. bitentaculata is very frequent from Mejillones to the Strait of Magellan (Kramp, 1966; Fagetti, 1973; Palma and Rosales, 1995; Pagès and Orejas, 1999; Pagès et al., 2001; Palma and Apablaza, 2004). This species is widely distributed in tropical and subtropical seas, mainly in the southern hemisphere, and in Antarctic and Sub-Antarctic waters (Kramp, 1952, 1968).

Amphogona apicata was most abundant in the areas least influenced by oceanic waters, such as the Moraleda Channel and interior sectors of the King and Ninualac channels (Fig. 5d), where EW and SAAMW predominated (Fig. 4). Abundance was similar to that registered in the Beagle Channel $\left(55^{\circ} \mathrm{S}\right)$, where this species was the most abundant medusa found between 100 and $400 \mathrm{~m}$ depth (Pagès and Orejas, 1999). A. apicata is a mesopelagic species widely distributed throughout the Atlantic but rarely observed in the Indian and Pacific oceans. In the Pacific, it has been found off New Zealand (Kramp, 1968), from Mexico to Peru (SeguraPuertas, 1984), and later in the Magellanic channels (Pagès and Orejas, 1999).

The high diversity values ( $>2.5$ bits) estimated for the Guafo Mouth and the oceanic stations in the King, Darwin, and Pulluche channels (Fig. 6) were due to the predominance of oceanic waters from the adjacent Pacific Ocean. In these areas, the density of medusae was lower and we collected several species that we did not find in the interior waters, such as Aglaura hemistoma, Amphinema rugosum, Dipurena sp., Hydractinia borealis and Liriope tetraphylla. A similar feature was found in the siphonophoran communities of in the same area (Palma and Rosales, 1997). 
The faunistic similarity among the stations of interior waters (Fig. 6), typified by the abundance of $H$. minuta, suggested that this species is highly associated with low salinity EW and does not proliferate in the more oceanic, higher-salinity waters with a marked prevalence of SAAMW below $50 \mathrm{~m}$ depth.

We also observed a significant correlation between the high densities of Hydractinia minuta and the low-temperature and low-salinity EW. The majority of Clytia spp. were found in areas with water temperatures associated with SAAMW.

\section{ACKNOWLEDGEMENTS}

The authors would like to thank the Comité Oceanográfico Nacional for financing Project CONA-C8F 02-12; the Captain and crew of the AGOR Vidal Gormaz of the Chilean Navy; and the sampling technicians for collaborating in the zooplankton hauls.

\section{REFERENCES}

Bouillon, J., M.D. Medel, F. Pagès, J.M. Gili, F. Boero and C. Gravili. - 2004. Fauna of the Mediterranean Hydrozoa. Sci. Mar., 68 (Suppl. 2): 5-438.

Brodeur, R, H. Sugisaki and G. Hunt Jr. - 2002. Increases in jellyfish biomass in the Bering Sea: implications for the ecosystem. Mar. Ecol. Progr. Ser., 233: 89-103.

Fagetti, E. - 1973. Medusas de aguas chilenas. Rev. Biol. Mar., Valparaíso, 15 (1): 31-75.

Guglielmo, L. and A. Ianora (eds.). - 1995. Atlas of marine zooplankton. Straits of Magellan. Copepods, 279 pp. SpringerVerlag, Berlin.

Guglielmo, L. and A. Ianora (eds.). - 1997. Atlas of marine zooplankton. Straits of Magellan. Amphipods, Euphausiids, Mysids, Ostracods, and Chaetognaths, 275 pp. SpringerVerlag, Berlin.

Guzmán, D. and N. Silva. - 2002. Caracterización física y química y masas de agua en los canales australes de Chile entra boca del Guafo y golfo Elefantes (Crucero Cimar-Fiordo 4). Cienc. Tecnol. Mar, 25 (2): 44-76.

Kramp, P. - 1952. Medusae. Reports of the Lund University Chile Expedition 1948-49. Acta Univ. Lund, NF Avd 2, 47 (7): 1-19.

Kramp, P. - 1966. A collection of Medusae from the coast of Chile. Vidensk. Medd. Dansk. Naturhist. Foren., 129: 1-38.

Kramp, P. - 1968. The Hydromedusae of the Pacific and Indian Oceans. Dana Rep., 72: 1-200.

Marín, V. and L. Delgado. - 2001. La taxocenosis de copépodos calanoídeos en los canales magallánicos: un patrón anidado. Cienc. Tecnol. Mar, 24: 81-89.

Matsakis, S. and R.J. Conover. - 1991. Abundance and feeding of Medusae and their potential impact as predators on other zooplankton in Bedford Basin (Nova Scotia, Canada) during spring. Can. J. Fish. Aquat. Sci., 48: 1419-1430.
Mills, C. - 2001. Jellyfish blooms: are populations increasing globally in response to changing ocean conditions? Hydrobiologia, 451: 55-68.

Mujica, A. and M. Medina. - 1997. Larvas de crustáceos decápodos de los canales australes de Chile. Cienc. Tecnol. Mar, 20: 147154.

Mujica, A. and M. Medina. - 2000. Distribución y abundancia de larvas de crustáceos decápodos en el zooplancton de los canales australes. Proyecto Cimar-Fiordos 2. Cienc. Tecnol. Mar, 23: 49-68.

Pagès, F. - 1992. Mesoscale coupling between planktonic cnidarian distribution and water masses during a temporal transition between active upwelling and abatement in the northern Benguela System. In: A.I.L. Payne, K.H. Brink, K.H. Mann and R. Hilborn (eds.), Benguela Trophic Functioning. S. Afr. J. Mar. Sci., 12: 41-52.

Pagès, F. and C. Orejas. - 1999. Medusae, siphonophores and ctenophores of the Magellan region. Sci. Mar., 63: 51-57.

Pagès, F., H. González, M. Ramón, M. Sobarzo and J.M. Gili. 2001. Gelatinous zooplankton assemblages associated with water masses in the Humboldt Current System and potential predatory impact by Bassia bassensis (Siphonophora: Calycophorae). Mar. Ecol. Progr. Ser., 210: 13-24.

Palma, S. - 1994. Composición y distribución del macroplancton gelatinoso recolectado frente a la costa central de Chile. Rev. Biol. Mar., Valparaíso, 29 (1): 2345.

Palma, S. and P. Apablaza. - 2004. Abundancia estacional y distribución vertical del zooplancton gelatinoso carnívoro en un área de surgencia en el norte del Sistema de la Corriente de Humboldt. Invest. Mar., Valparaíso, 32 (1): 49-70.

Palma, S. and G. Aravena. - 2001. Distribución de quetognatos, eufáusidos y sifonóforos en la región magallánica. Cienc. Tecnol. Mar, 24: 47-59.

Palma, S. and G. Aravena. - 2002. Distribución estacional y vertical de los quetognatos colectados entre el golfo Corcovado y el estero Elefantes. Cienc. Tecnol. Mar, 25 (2): 87-104.

Palma, S. and S. Rosales. - 1995. Composición, abundancia y distribución estacional del macrozooplancton de la bahía de Valparaíso. Invest. Mar., Valparaíso, 23: 49-66.

Palma, S. and S. Rosales. - 1997. Sifonóforos epipelágicos de los canales australes de Chile $\left(41^{\circ} 30^{\prime}-46^{\circ} 40^{\prime}\right.$ S). Cienc. Tecnol. Mar, 20: 125-146.

Palma, S. and N. Silva. - 2004. Distribution of siphonophores, chaetognaths and euphausiids and oceanographic conditions in the fjords and channels of southern Chile. Deep-Sea Res. II, 51: 513-535.

Palma, S., R. Ulloa and L. Linacre. - 1999. Sifonóforos, quetognatos y eufáusidos de los canales australes entre el golfo de Penas y el estrecho de Magallanes. Cienc. Tecnol. Mar, 22: 111-142.

Rojas, R., D. Guerra, G. Otárola and N. Silva. - 2005. CD-ROM Reporte de Datos del Crucero Oceanográfico CIMAR 8 Fiordos. Centro Nacional de Datos Hidrográficos y Oceanográficos de Chile (CENDHOC). Servicio Hidrográfico y Oceanográfico de la Armada (SHOA). Revised in January 2006.

Segura-Puertas, L. - 1984. Morfología, sistemática y zoogeografía de las medusas (Cnidaria: Hydrozoa y Scyphozoa) del Pacífico Tropical Oriental. Instituto de Ciencias del Mar y Limnología. Univ. Nac. Autón. Méx., Publ. Espec., 8: 1-320.

Silva, N., C. Calvete and H. Sievers. - 1998. Masas de agua y circulación general para algunos canales australes entre Puerto Montt y Laguna San Rafael (Crucero Cimar-Fiordo 1). Cienc. Tecnol. Mar, 21: 17-48.

Scient. ed.: F. Pagès.

Received January 26, 2006. Accepted September 26, 2006.

Scient. ed.: February 6, 2007. 